\title{
Geospatial Analysis and Simulation of Glacial Avalanche Hazard in Hunza River Basin
}

\author{
N. Gilany, J. Iqbal, and E. Hussain
}

\begin{abstract}
Glacial avalanche hazard poses threat to human lives and damage settlements / infrastructures in alpine glaciers mountainous regions. A gigantic ice plus rock avalanche destroyed Gyari military camp in Siachen sector on April 2012 and buried 139 personals. The study focuses on geospatial analysis and simulation of Shishper glacial avalanche of Hunza basin. To simulate the potential glacial avalanche hazard to Hassan Abad settlements, an empirical process based Glacier Avalanche Model; Rapid Access Mass Movement Simulation (RAMMS) is utilized. The model encompasses avalanche release area and height for the execution of simulation. The model output of Shishper glacial avalanche resulted; a max pressure of $450 \mathrm{Kpa}$, max velocity of $40 \mathrm{~m} / \mathrm{s}$, and the max flow height of $80 \mathrm{~m}$, while the resulted surge extent output was $2500 \mathrm{~m}$. The potential hazardous Shishper glacial avalanche remains a continuous hazard to Hassan Abad of Hunza valley including Karakoram Highway and Frontier Works Organization (FWO) camp. The study has resulted in identifying the Upper Indus Bain (UIB) being more prone to glacial avalanche hazards because of host factors in general and the anthropogenic factor in particular.
\end{abstract}

Index Terms-Hazard, anthropogenic, glacial, simulation.

\section{INTRODUCTION}

The alpine glaciers of the sub-continent region are a renewable natural freshwater storehouse that benefits millions of people downstream. Owing to global warming acceleration, the glaciers of the mid-latitude region are retreating since the second half of the 20th century. The retreating glacier phenomenon has accounted for the generation of many disastrous avalanches. The disastrous glacial avalanches containing debris and a large quantity of turbulent mass lead to the sudden breaches of these unstable moraines which hold huge quantities of glacial mass [1]. It is likely that glacier-connected lakes may have accelerated the glacial mass movement via thermal energy transmission and contributed to the significant area loss in their connected glaciers. The significant glacial retreats led to disconnections from their pro-glacial lakes, which appeared to destabilize the glaciers in the Himalaya. Continuous formation of the glacial lakes connected with debris-covered glaciers, therefore, need additional attention due to their growing potential outflows [2]. The ice avalanches are the indicators of the regular depletion phenomenon of the steep glaciers in higher elevation ranges having high relief energy. When the

Manuscript received January 18, 2020; revised November 19, 2020. This work was supported by Pakistan Meteorological Department.

The authors are with IGIS, NUST, Pakistan (e-mail: naseemphd13@igis.nust.edu.pk, ejaz@igis.nust.edu.pk). glacial avalanches are coupled with debris, then extreme disasters are caused by these avalanches. Ice avalanche usually occurs, once a huge mass of ice detaches from a limp glacier. Human lives and structures have been affected by avalanches in Alps, Kashmir, Iceland, Afghanistan, Caucasus and Canada [3].

The frequency of glacier-dammed lakes and outflows in the Karambar valley of Hindukush-Karakoram has increased risk to infrastructure and living organisms in this region [4]. The glacier surge is a seasonal phenomenon owing to the extreme flow velocities resulting in the rapid mass movement of turbulent glacial mass [5]. The balance in accumulation and ablation zones of a glacier is very vital for its stability. A hydro-meteorological perspective on the anomaly of glacier dynamics has originated the argument of heavy accumulation zones, thus disturbing the mass balance [6]. The natural stability and behavior of the glacier are very much dependent on slope, elevation, aspect, and geomorphology of the vicinity [7]. Glacier expansion is very much related to the elevation from mean sea level in the Karakoram region [8]. Himalayan glaciers are a focus of public and scientific debate. Prevailing uncertainties are of major concern because some projections of their future have serious implications for water resources. Most Himalayan glaciers are losing mass at rates similar to glaciers elsewhere; except for emerging indications of stability or mass gain in the Karakoram [9]. Rising global temperature is the major factor in the glacial lake formation which is caused by the glacial retreat in mountainous regions. In the era of 1550 to 1850 , the glaciers were quite in length in comparison with today. With the inception of global warming, moraines formation adjacent to glaciers blocks the glacial lakes [10].

Since the Little Ice Age, the glaciers of the Himalaya have experienced a significant retreat in length. The situation leads to the glaciers disturbance, formation of moraine-dammed lakes and frequent glacial mass movement [11]. The proximity analysis of the settlements with respect to glacial lakes is very vital with respect to geospatial analysis and modeling of glacial hazards in Hunza basin of Pakistan. Glacial avalanche is the critical hazard which effects buildings, roads and poses threat to humanity in mountainous regions. The glacial dynamics of Pakistan alps are underexplored and unique due to diversity of factors and lack of previous studies. In the past 20 years, glaciers in the Himalaya have retreated and thinned rapidly as a response to regional climate warming, leading to the formation of new glacial lakes thus causing triggering of glacial avalanches. These areas are located in the border belt and the Eurasian plates, where tectonic seismic activity is frequent and intense. Earthquakes have often compromised the stability of 
mountain slopes, glaciers, and moraine dams, resulting in an imbalance in the state of glacial mass [12]. Much of the damage created during glacial avalanche events is associated with the large amounts of debris that accompany the glacial mass. During recent past decades there has been a rapid retreat of glaciers of Pakistan, new lakes are being formed, and the de-stabilization of the attached glaciers is increasing. Damages to settlements and farmland can take place at very great distances from the outflow source [13]. The diversity of glacial material is the prime reason for the diverse and peculiar dynamics of the glaciers. Heterogeneity in the Karakoram glacier surges is observed because of the peculiar dynamics of the glaciers [14]. The glacier surges are propagated coupled with glacial lakes. Glacier changes in the Karakoram region are mapped temporally in order to observe the diverse behavior of the glaciers [15]. A conceptual analysis model of supra-glacial lake formation on debris-covered glaciers is based on GPR (Ground Penetrating Radar). On debris-covered glaciers, glacial lake formation is observed at a faster pace in alpine region of Pakistan [16]. The analysis has put forth the argument of increased melting observed in glaciers of northern Pakistan. The risk factor increases exponentially with the presence of supra-glacial lakes, the trend is observed through risk assessment of glacial hazards [17]. The stipulated cause of more glacial avalanche events in the region is the change in the rainfall pattern [18].

Formation of glacial lake phenomenon has rapidly increased owing to global warming. Glaciological characteristics of the ablation zone of Siachen glacier have changed in the recent past because of host of factors [19]. Glacier-fed lakes are dominant in both quantity and area and exhibit an overall faster expansion trend compared to the non-glacier-fed lakes in the Himalayas [20]. On 07 Apr 2012 in Siachen sector of Pakistan, a military camp situated in Gyari suffered from a massive glacial avalanche resulting burial of 139 soldiers and civilians under a huge mass of debris/ snow. The investigations and monitoring including geospatial analysis and modeling of glacial hazards had never been performed before Gyari incident in Upper Indus Basin of Pakistan, and that is the major cause of that incident happening [21]. A historic glacial outflow had a depth of around $30 \mathrm{~m}$ at Shimshal in Hunza basin, and destroyed the village of Passu [22]. The Hunza river basin at places warrants situations that exhibit unstable glacial mass movement at multiple places, leading to the glacial hazards [23]. The infrastructure including houses, buildings and farmlands in avalanche-prone area of Hassan Abad in Hunza basin remains threatened because of continuous glacial mass movement of Shishper glacier. This study proposes a need to establish a concrete scientific context which can be ultimately fed to more encompassing predictive frameworks for early warning of potential hazards in the area. The study contributes in simulation of potential hazardous Shishper glacial avalanche of Hunza basin in order to generate an early warning to Hassan Abad habitation.

\section{Methods AND Materials}

\section{A. Avalanche Formation and Release}

Avalanche formation and release is complex phenomenon with various determining factors related to avalanche types such as loose or slab, snowpack features, meteorological elements, and terrain structures. Topographical characterization of terrain determines snow strength, avalanche relief, and avalanche indication along with the run-out. The dynamics are collectively called avalanche formation. Meteorological elements influencing strength comprises of air temperature, wind, relative humidity, solar radiation, long wave radiation, snow accumulation rates, snow depth, and rainfall. These elements subsidize the development of weak strata inside the snowpack. Moreover, fresh precipitation ahead of a snowpack might activate a weak stratum to apart an avalanche. The glacial hazards assessment process is often based on comprehensive knowledge base and capabilities extended for past events. An integrated overview of the detailed investigations of the chain reactions and glacier avalanche disasters is required. The numerical parameters concerning slope and avalanche probability of the ice avalanches as shown in Table I are mainly the resultant of case studies in the Swiss Alps [24].

TABLE I: SLOPE AND AVALANCHE PROBABILITY

\begin{tabular}{cl}
\hline \hline Slope & \multicolumn{1}{c}{ Avalanche Probability } \\
\hline $0^{\circ}-10^{\circ}$ & Practically no avalanches are triggered \\
$10^{\circ}-28^{\circ}$ & Avalanches are scarce \\
$28^{\circ}-45^{\circ}$ & $\begin{array}{l}\text { The major danger zone for avalanche triggering } \\
\text { High avalanche frequency, low snow accumulation due to } \\
45^{\circ}-60^{\circ}\end{array}$ \\
\hline \hline
\end{tabular}

\section{B. Mathematical Models for Glacial Avalanches}

The integrated models for characterizing dynamics of glacial avalanches and facilitating quantitative investigation have been proposed as early as 1955 [25].

\section{1) Voellmy Salm (VS) model}

The simplest of the model is the Voellmy-Salm (VS) model which is embedded for avalanche run-out calculation [26]. The VS model is incomplete since it calculates neither the dispersal of the snow mass as it moves down the mountainside, neither the instantaneous velocity field, nor the deposition area in the run out zone [27]. Moreover, the run out distance is calculated with respect to the center of mass and not the leading edge of the avalanche [28].

\section{2) Random kinetic energy (RKE) model}

The model solves depth-averaged mass and momentum conservation equations for avalanche flow in general three-dimensional terrain using a second-order finite-volume method [29]. The output results of the RKE model support the hypothesis that the production of random kinetic energy within the flow is of relevance in the run-out of rock avalanches. The introduction of the random energy requires redefining the energy balance because the energy source, the gravitational work rate, is split into kinetic, internal and random energy components. The RKE model is based on full-scale observations of dense granular snow avalanches, possibly the only gravitational mass movements where the evolution of shearing within the avalanche flow body has been experimentally measured [30]. The fluctuating motion of the snow granules can only decay by collisional processes, producing heat and only heat. The irreversibility of the 
random energy implies that it is a type of internal energy, similar to heat, but not yet heat. However, unlike heat, R must disappear when the avalanche stops.

3) Rapid access mass movement simulation (RAMMS) model

In order to make an assessment of the avalanche hazard extent, 1D mathematical model, such as AVAL-1D is used in Switzerland, America, Europe and Asia [31]. The avalanche flow size and flow course are to be marked by the user in 1D model. 2D and 3D models require a complete procedure to fulfill the topography requirements and release parameters. However, the handling of flow rheology is the major problem in all these 1, 2 and 3D models. RAMMS model is a precise estimation of glacial avalanche flow velocity, flow height, influenced pressure and run out distances in the normal 3D environment [32]. Both Voellmy-Salm (VS) and Random Kinetic Energy (RKE) are utilized to deal with the flow rheology in RAMMS model. It is a statistical model which is nearly realistic in order to estimate the extents of potential hazard-prone areas in future and for the determination of past known avalanche happenings at specific locations. RAMMS is a computer-based model for simulation of glacier avalanche which is highly reliable. The methodological flowchart for the RAMMS model is as shown in Fig. 1.

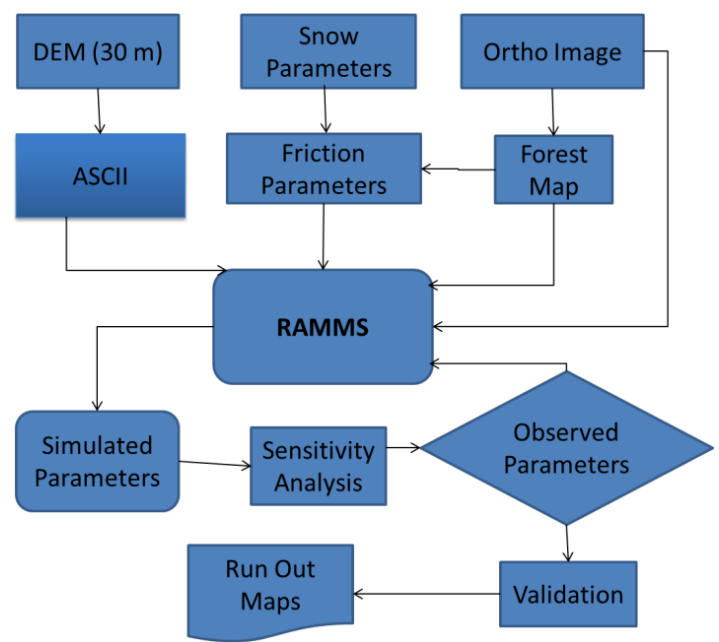

Fig. 1. Methodological framework of RAMMS.

The model has been validated for verification with a number of happenings of avalanches. The model outputs are used for estimation of flow velocities, flow heights, run out distances and influence forces. Geo-referenced maps and airborne images are also incorporated into RAMMS. The different input parameters required to accomplish the mathematical scheming of RAMMS are DEM, fracture height, release zone, friction parameters, avalanche return period, avalanche volume category, snow / glacier density, forest parameters, aerial / satellite imagery and domain area.

\section{Study Area}

The study area comprises of Hunza River basin (Fig. 2). The study area has also an importance from the strategic point of view as FWO camp is situated here.

\section{Data and Materials}

The Hunza basin is situated in the Upper Indus Basin which contains many of the hazardous glaciers. Following datasets were utilized for the study:-

\section{1) Remotely sensed satellite data}

The pre and post-disaster GeoEye high-resolution imagery acquired from Google Earth Pro of Hunza basin.

\section{2) Digital elevation model}

The basic input for glacier avalanche simulation is ASTER DEM of $30 \mathrm{~m}$ resolution. At an altitude of $>14000 \mathrm{ft}$, glaciers are stable and at an altitude of $<14000 \mathrm{ft}$, glaciers are more prone to glacial hazards [33].
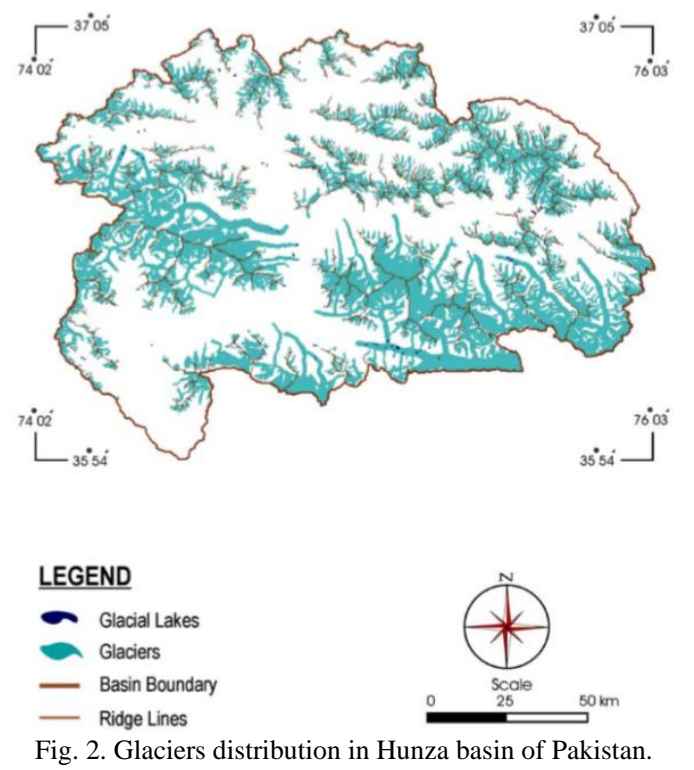

\section{E. Remote Sensing Application in Avalanche Simulation}

Remote sensing mechanisms are capable of getting information in excess of large regions deprived of limitations produced by poor ground convenience [34]. The remote sensing is used to get the information of snow cover attributes like snow depth, water content, and diameter of snow particles [35]. Digital Terrain Model (DTM) of the glaciated areas helps in identification of the steepness of glaciers [36]. High resolution and accurate remote sensing data allow observation of mass variations involving kinematics [37].

\section{F. GIS Application in Avalanche Simulation}

Geographic Information Systems (GIS) has strengthened avalanche research simulation by extraction of terrain attributes for analysis of the formation and release phenomenon of avalanches [38]. By using GIS the avalanche release zones can be defined by analyzing aspect, slope, and elevation curves from Digital Elevation Model (DEM) [39].

\section{RESULTS AND DISCUSSIONS}

In most of the regions of the world, especially where there is poor documentation of natural hazards, the destruction caused to human lives and properties by glacial avalanches remain underestimated. Upper Indus Basin is one of the regions where, in every winter, numerous settlements are threatened by massive glacial avalanches. RAMMS model is used for assessment of glacial hazard in the current study of simulation and modeling of potential hazardous glacial 
avalanches. The Remote Sensing techniques were used in the study for determination of glacial hazard coupled with ArcGIS software for geospatial analysis in Hunza basin. Keeping in view the climatological and geomorphological variables, coupled with satellite imagery analysis the preventive measures be taken in time to avoid the Shishper glacier avalanche disaster.

\section{A. Shishper Glacier Avalanche of Hunza Basin}

As of investigation originated from the interpretation of satellite imagery, geomorphological, climatological and the proximity analysis of the potentially dangerous Shishper glacier, it was revealed that the glacier is prone to generation of an avalanche thus causing hazard to the settlements of Hassan Abad (Fig. 3). Hassan Abad is a village located in Ali Abad Tehsil of Hunza District, in the Gilgit-Baltistan region of Pakistan. It lies at an altitude of 2,100 m above sea level and is known for hydro power generation in Hunza Valley. Karakoram Highway (KKH) crawls through Hassan Abad with a total length of $5 \mathrm{~km}$. The total area of Hassan Abad is $2.1 \mathrm{~km}^{2}$ and there are around 350 inhabitants with a total of 70 houses.

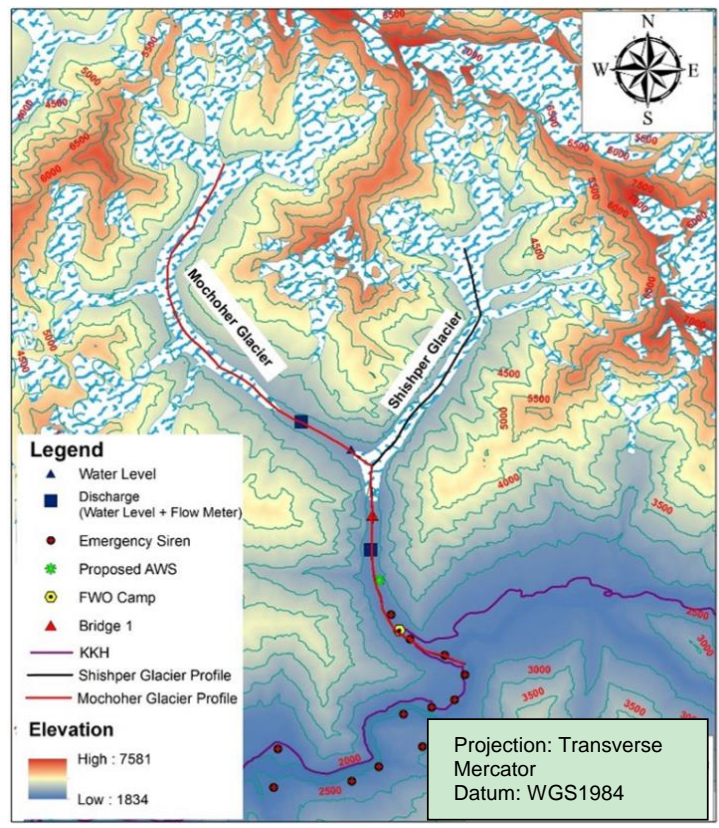

Fig. 3. Topographic profile of Shishper glacier surroundings down to KKH. Picture obtained from Pakistan Meteorological Department (PMD).

A lot of work is done to emerge a Graphical User Interface (GUI) for RAMMS model which made it quite easy to use. A graphical view of mathematical calculations is essential to assess the goodness of simulated outputs. Avalanches flow in open channel and close gullies in mountains and RAMMS is the authenticated model to assess the avalanche run-out distances, flow velocities, entrainment depths, and flow heights [40]. The RAMMS input model parameters like release area and its height were put in and simulated many times to actualize the height and debris 2D extent (Fig. 4).

The RAMMS model creates an output data log file which was certainly loaded afterward showing the accomplishment of the mathematical calculation. Release zones are specified using polygons generated within RAMMS. The results in terms of shape files from GIS-based terrain analysis are also imported into RAMMS. These release zone and fracture height parameters are required for large scale hazard mapping with RAMMS. For every release zone area defined, the avalanche anticipated fracture height is selected. Automated procedures are available within RAMMS to calculate the fracture height based on the Swiss Guidelines. The release area of Shishper glacier avalanche which was incorporated for simulation of glacial outflow was 0.84 sq. $\mathrm{km}$ and the fracture height selected as input to the RAMMS was $3000 \mathrm{~m}$ as shown in Table II.

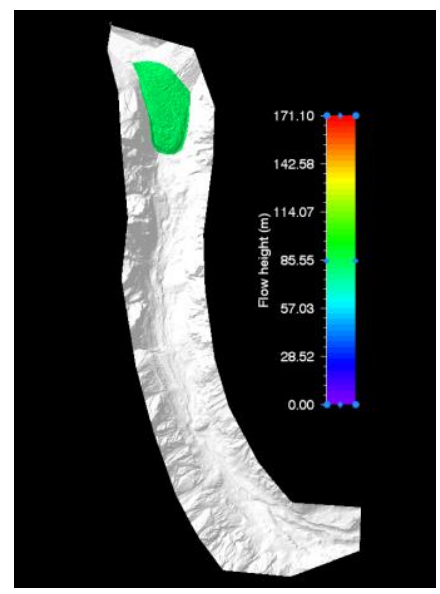

Fig. 4. Release area of Shishper glacier avalanche. Image prepared in RAMMS model version 1.7.0.

TABLE II: GENERAL INPUTS AND VALUES REQUIRED FOR RAMMS

\begin{tabular}{cll}
\hline \hline Ser. & \multicolumn{1}{c}{ Inputs } & $\begin{array}{l}\text { Values for Shishper } \\
\text { Glacier }\end{array}$ \\
\hline 1. & Digital Elevation Model & ASTER $30 \mathrm{~m}$ \\
2. & Fracture Height and Release & $3000 \mathrm{~m}$ and 0.84 sq. km \\
& Zone & \\
3. & Friction Parameters & Constant \\
4. & Avalanche Return Period & 30 Years \\
5. & Avalanche Volume Category & Large \\
6. & Snow / Glacier Density & $917 \mathrm{kgm}^{-3}$ \\
7. & Forest Parameters & No Forest Cover \\
8. & Aerial / Satellite Imagery & GeoEye \\
9. & Domain Area & Shape File \\
\hline \hline
\end{tabular}

\section{B. Rapid Access Mass Movement Simulation of Shishper Glacier Avalanche}

The output of modeled glacier avalanche flow height for Shishper glacier avalanche was ranged from $20 \mathrm{~m}$ to $80 \mathrm{~m}$ which was superimposed on the topography as shown in Fig. 5(a).

The RAMMS model simulated the velocity of $40 \mathrm{~m} / \mathrm{s}$ for Shishper glacier avalanche. The max flow velocity for Shishper glacier avalanche molded by RAMMS model was a little bit low as compared to flow velocity of Gyari glacier avalanche which was $74 \mathrm{~m} / \mathrm{s}$ [41]; this could be due to the difference in the slope and mass of the detached glacier slab. The avalanche flow velocity simulated by RAMMS model for Shishper glacier avalanche was superimposed on the topography as shown in Fig. 5(b).

Avalanche flow momentum modeled by RAMMS for Shishper glacier avalanche was ranged from a value of 400 $\mathrm{m}^{2} / \mathrm{s}$ to $1000 \mathrm{~m}^{2} / \mathrm{s}$. Later the momentum output was superimposed on the topography as shown in Fig. 5(c).

RAMMS model avalanche flow pressure simulation for Shishper glacier avalanche was $450 \mathrm{Kpa}$ which was superimposed on the topography as shown in Fig. 5(d). 
The topography can be portrayed in flat 2D or completely in $3 \mathrm{D}$. The overlaid output is envisioned at every step for complete simulation saved through defined steps. The color profiles of modeled flow height, velocity, momentum, and pressure of Shishper glacier avalanche allow a ready reckoner type determination of flow height, velocity, momentum, and pressure being entrained in front or tail of the avalanche at gullies or run out zones track sections.

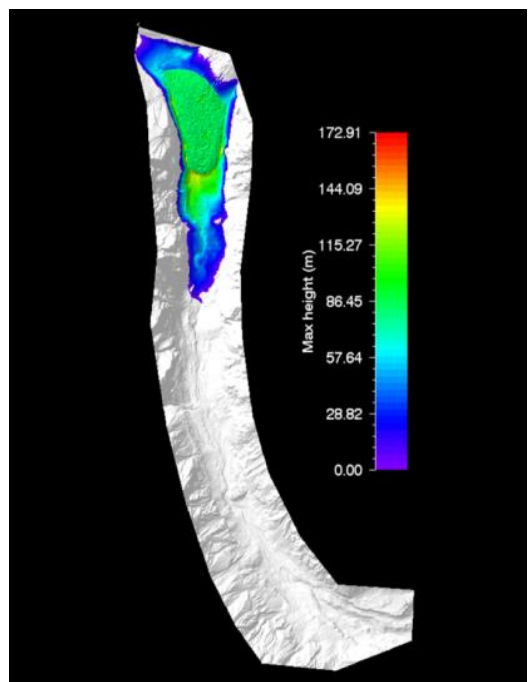

Fig. 5. (a) Max height of Shishper glacier avalanche. Images prepared in RAMMS model version 1.7.0.

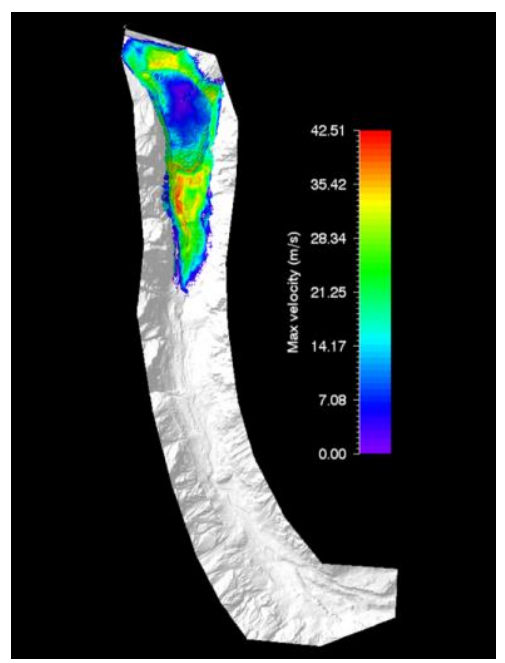

Fig. 5. (b) Max velocity of Shishper glacier avalanche. Images prepared in RAMMS model version 1.7.0.

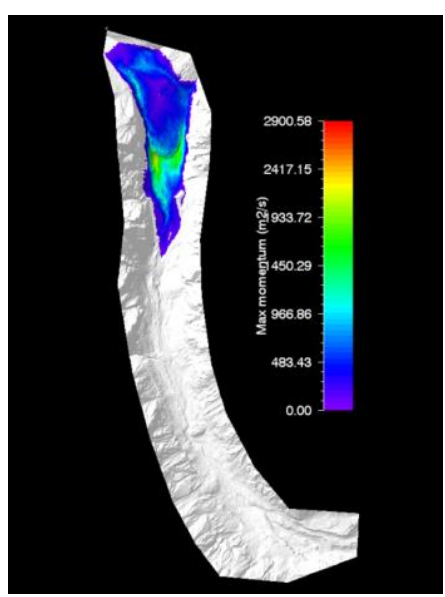

Fig. 5. (c) Max momentum of Shishper glacier avalanche. Images prepared in RAMMS model version 1.7.0.

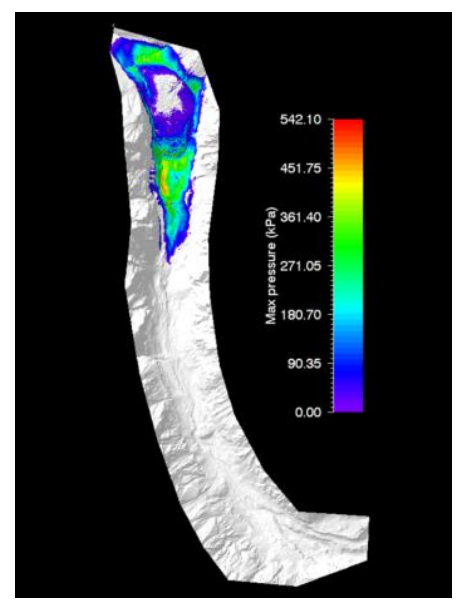

Fig. 5. (d) Max pressure of Shishper glacier avalanche. Images prepared in RAMMS model version 1.7.0.

\section{RAMMS Output Parameters of Shishper Glacier Avalanche}

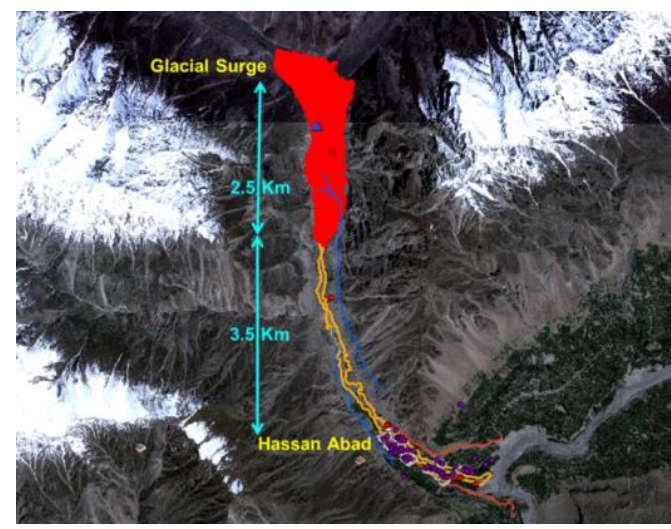

Fig. 6. Glacial surge hazard simulation of Shishper glacier avalanche (Post-disaster). Image captured from Google Earth utilized in RAMMS model version 1.7.0.

TABLE III: RAMMS OUTPUT PARAMETERS OF SHISHPER GLACIER

\begin{tabular}{|c|c|c|}
\hline \multicolumn{3}{|c|}{ AVALANCHE } \\
\hline $\begin{array}{c}\text { Output } \\
\text { Parameter }\end{array}$ & $\begin{array}{c}\text { Value } \\
\text { Obtained }\end{array}$ & Description \\
\hline Flow Height & $20-80 \mathrm{~m}$ & $\begin{array}{l}\text { Flow height obtained during the } \\
\text { course of avalanche }\end{array}$ \\
\hline $\begin{array}{l}\text { Velocity } \\
\text { Generated }\end{array}$ & $25-40 \mathrm{~m} / \mathrm{s}$ & $\begin{array}{l}\text { Velocity of moving mass of } \\
\text { avalanche }\end{array}$ \\
\hline Pressure Exerted & $50-450 \mathrm{Kpa}$ & Thrust Pressure of avalanche \\
\hline $\begin{array}{l}\text { Momentum } \\
\text { Gained }\end{array}$ & $\begin{array}{l}400-1000 \\
\mathrm{~m}^{2} / \mathrm{s}\end{array}$ & $\begin{array}{l}\text { Volumetric momentum of glacial } \\
\text { mass }\end{array}$ \\
\hline Surge Extent & $2500 \mathrm{~m}$ & $\begin{array}{l}\text { Extent of surge of glacial mass of } \\
\text { avalanche }\end{array}$ \\
\hline
\end{tabular}

RAMMS model outputs coupled with the ArcGIS environment revealed better interpretation and improved spatial analysis of the output results of the simulation as shown in Fig. 6. Sequel to Shishper glacier surge since Apr 2019, the glacier's continuous surging downstream can cause disaster to Hassan Abad habitat. The glacier surge is causing rapid mass movement downstream, thus a glacial avalanche blockage threat is foresighted to Karakoram highway. During the field visit it was revealed that the fragmented snout of the surging glacier is continuous hazard to the settlements downstream. Site analysis dictates complete blockade is filled with dammed glacial water, ice mass and rock debris which can trigger mass movement. The in-situ measurements of run out distances of surging glacier have been analyzed 
with reiterative simulations of RAMMS. Rapid access mass movement simulation based on present condition of Shishper glacier surge shows $2500 \mathrm{~m}$ further downstream surge of the glacier.

RAMMS model output parameters of flow velocity, height, pressure, and momentum of Shishper glacier avalanche are shown in Table III.

\section{CONCLUSION}

The RAMMS model is an effective tool for simulation and modeling of glacier avalanche hazard. The reiterative simulation results of the application of RAMMS model for simulation of Shishper glacier avalanche indicated that RAMMS closely reproduces run out distances in 2D and 3D terrain. Flow widths were well modeled for the starting and transit zones by using statistical parameters utilized by many experts in glacier avalanche assessment. The analysis is based on DEM in order to identify in between the channel, gully regions and open slopes. RAMMS model is effectively being used worldwide for hazard assessment studies, especially because it contains both RKE model and VS model features preserving many of the features of these models and can precisely predict the spatial distribution of the avalanche debris deposits. In Hunza basin, Shishper glacier is continuously surging and causing rapid mass movement downstream. The fragmented snout of the surging glacier is continuous hazard to the settlements of Hassan Abad downstream. The simulation based on RAMMS model dictates that in present condition of Shishper glacier mass movement, a $2500 \mathrm{~m}$ further downstream surge is expected which may further grow based on the incremental release area. The residents of Hassan Abad can be sensitized to undertake Community Based Disaster Risk Management (CBDRM) including drills, procedures and rehearsals for logistics and evacuation places. In Hunza basin the RAMMS model simulation analysis revealed that FWO camp is situated in the course of glacier avalanche and is an avalanche hazard prone area along with settlements of Hassan Abad. Moreover, by incorporating the RAMMS simulation results, the settlements near the other identified glacier avalanche hazard-prone areas can be safeguarded to avoid the destructive incident like Gyari in future.

\section{CONFLICT OF INTEREST}

The authors declare no conflict of interest.

\section{AUTHOR CONTRIBUTIONS}

Mr. Naseem Gilany wrote the main manuscript text including figures, Dr. Javed Iqbal reviewed the manuscript and Dr. Ejaz Hussain carried out the structural organization of the manuscript.

\section{ACKNOWLEDGMENT}

We are sincerely obliged to IGIS-NUST for providing us platform of a knowledge base during the study period. We are very thankful to SUPARCO for cooperation and help in this research work. We acknowledge PMD (Pakistan) for the provision of data support for this paper.

\section{REFERENCES}

[1] R. Bhambri et al., "Heterogeneity in glacier response in the upper Shyok valley, northeast Karakoram," The Cryosphere, vol. 7, no. 5, pp. 1385-1398, 2013.

[2] Y. Nie et al., "An inventory of historical glacial lake outburst floods in the Himalayas based on remote sensing observations and geomorphological analysis," Geomorphology, vol. 308, pp. 91-106, 2018.

[3] F. Sigurdsson, G. G. Tomasson, and F. Sandersen, "Avalanche defenses for Flateyri, Iceland. From hazard evaluation to construction of defenses," VST consulting Engineers, 2000.

[4] L. Iturrizaga, "Historical glacier-dammed lakes and outburst floods in the Karambar valley (Hindukush-Karakoram)," GeoJournal, vol. 63 , no. 1-4, pp. 1-47, 2005.

[5] J. F. Steiner et al., "Brief communication: The Khurdopin glacier surge revisited-extreme flow velocities and formation of a dammed lake in 2017," The Cryosphere, vol. 12, no. 1, pp. 95-101, 2018.

[6] F. Bashir et al., "A hydrometeorological perspective on the Karakoram anomaly using unique valley-based synoptic weather observations," Geophysical Research Letters, vol. 44, no. 20, pp. 10,470-10,478, 2017.

[7] S. N. A. Gilany and J. Iqbal, "Glacial avalanche hazard's comparative geospatial analysis in shigar and shyok basins," International Journal of Environmental Science and Development, vol. 9, no. 1, 2018.

[8] K. Hewitt, "The Karakoram anomaly? Glacier expansion and the 'elevation effect,' Karakoram Himalaya," Mountain Research and Development, vol. 25, no. 4, pp. 332-341, 2005.

[9] T. Bolch et al., "The state and fate of Himalayan glacier," Science, vol. 336, no. 6079, pp. 310-314, 2012.

[10] M. Bhutiyani," Mass-balance studies on Siachen glacier in the Nubra valley, Karakoram Himalaya, India," Journal of Glaciology, vol. 45, no. 149, pp. 112-118, 1999.

[11] P. K. Mool et al., "Inventory of glaciers, glacial lakes and glacial lake outburst floods. Monitoring and early warning systems in the Hindu Kush-Himalayan Region: Bhutan. Inventory of glaciers, glacial lakes and glacial lake outburst floods," Monitoring and Early Warning Systems in the Hindu Kush-Himalayan Region: Bhutan, 2001.

[12] S. Wang and L. Zhou, "Glacial lake outburst flood disasters and integrated risk management in China," International Journal of Disaster Risk Science, vol. 8, no. 4, pp. 493-497, 2017.

[13] S. R. Bajracharya and P. Mool, "Glaciers, glacial lakes and glacial lake outburst floods in the Mount Everest region, Nepal," Annals of Glaciology, vol. 50, no. 53, pp. 81-86, 2017.

[14] D. J. Quincey et al., "Heterogeneity in Karakoram glacier surges," Journal of Geophysical Research: Earth Surface, vol. 120, no. 7, pp. 1288-1300, 2015.

[15] M. Rankl, C. Kienholz, and M. Braun, "Glacier changes in the Karakoram region mapped by multimission satellite imagery," The Cryosphere, vol. 8, no. 3, pp. 977-989, 2014.

[16] J. R. Mertes et al., "A conceptual model of supra-glacial lake formation on debris-covered glaciers based on GPR facies analysis," Earth Surface Processes and Landforms, vol. 42, no. 6, pp. 903-914, 2017.

[17] J. M. Lala, "Modeling and risk assessment of glacial lake outburst floods (GLOFs): A case study of Imja Tsho in the Nepal Himalayas," 2018.

[18] I. Ahmad, "Hydrology of mountainous areas in the upper Indus Basin, Northern Pakistan with the perspective of climate change,' Environmental Monitoring and Assessment, vol. 184, no. 9, pp 5255-5274, 2012.

[19] C. Mayer et al., "Glaciological characteristics of the ablation zone of Baltoro glacier, Karakoram, Pakistan,” Annals of Glaciology, vol. 43, pp. 123-131, 2006

[20] R. A. Mir et al., "Glacier recession and glacial lake outburst flood studies in Zanskar basin, western Himalaya," Journal of Hydrology, vol. 564, pp. 376-396, 2018.

[21] A. Kääb et al., "Contrasting patterns of early twenty-first-century glacier mass change in the Himalayas," Nature, vol. 488, no. 7412, p. 495,2012

[22] A. Goudie, "The geomorphology of the Hunza valley, Karakoram mountains, Pakistan," The International Karakoram Project, vol. 2, pp. 359-410, 1984.

[23] D. Yongjian and L. Jingshi, "Glacier lake outburst flood disasters in China," Annals of Glaciology, vol. 16, pp. 180-184, 2017.

[24] J. Alean, "Ice Avalanches: Some Empirical Information about their formation and reach," Journal of Glaciology, vol. 31, no. 109, pp. 324-333, 2017. 
[25] A. Voellmy, "Uber die Zerstorungskraft von Lawinen," Schweizerische Bauzeitung, Jahrg., vol. 73, pp. 159-162, 212-217, 246-249, 280-285, 1955.

[26] B. Salm, A. Burkhard, and H. Gubler, Berechnung von Fliesslawinen: eine Anleitung für Praktiker mit Beispielen, Eidgen. Inst. für Schnee-und Lawinenforschung, 1990.

[27] K. Hutter, S. B. Savage, and Y. Nohguchi, "Numerical, analytical, and laboratory experimental studies of granular avalanche flows," Annals of Glaciology, vol. 13, pp. 109-116, 2017.

[28] D. McClung and A. Mears, "Dry-flowing avalanche run-up and run-out," Journal of Glaciology, vol. 41, no. 138, pp. 359-372, 1995.

[29] P. Bartelt, O. Buser, and K. Platzer, "Fluctuation-dissipation relations for granular snow avalanches," Journal of Glaciology, vol. 52, no. 179 , pp. 631-643, 2006.

[30] M. Kern et al., "Measured shear rates in large dry and wet snow avalanches," Journal of Glaciology, vol. 55, no. 190, pp. 327-338, 2009.

[31] M. Christen, P. Bartelt, and J. Kowalski, "Back calculation of the $\langle$ I $>$ In den Arelen</I > avalanche with RAMMS: Interpretation of model results," Annals of Glaciology, vol. 51, no. 54, pp. 161-168, 2010.

[32] M. Christen, J. Kowalski, and P. Bartelt, "RAMMS: Numerical simulation of dense snow avalanches in three-dimensional terrain," Cold Regions Science and Technology, vol. 63, no. 1-2, pp. 1-14, 2010.

[33] N. Gilany and J. Iqbal, "Simulation of glacial avalanche hazards in shyok basin of upper indus," Scientific Reports, vol. 9, no. 1, p. 20077 , 2019 ,.

[34] M. Barbolini et al., "Application of statistical and hydraulic-continuum dense-snow avalanche models to five real European sites," Cold Regions Science and Technology, vol. 31, no. 2, pp. 133-149, 2000.

[35] S. P. Pudasaini and K. Hutter, "Avalanche dynamics: dynamics of rapid flows of dense granular avalanches," Berlin, New York: Springer, 2007.

[36] J.-T. Fischer, J. Kowalski, and S. P. Pudasaini, "Topographic curvature effects in applied avalanche modeling," Cold Regions Science and Technology, pp. 21-30, 2012.

[37] C. Huggel et al., "Remote sensing based assessment of hazards from glacier lake outbursts: A case study in the Swiss Alps," Canadian Geotechnical Journal, vol. 39, no. 2, pp. 316-330, 2002

[38] D. M. McClung and P. A. Schaerer, "Characteristics of flowing snow and avalanche impact pressures," Annals of Glaciology, vol. 6, pp. 9-14, 2017.

[39] P. Bartelt and B. W. McArdell, "Granulometric investigations of snow avalanches," Journal of Glaciology, vol. 55, no. 193, pp. 829-833, 2017.

[40] H. Gusain, V. Mishra, and D. Singh, "Study of a snow avalanche accident along chowkibal-tangdhar road in Kupwara district, Jammu and Kashmir, India," Current Science, vol. 115, pp. 969-972, 2018.

[41] M. A. Mahboob, J. Iqbal, and I. Atif, "Modeling and simulation of glacier avalanche: a case study of gayari sector glaciers hazards assessment," IEEE Transactions on Geoscience and Remote Sensing, vol. 53, no. 11 , pp. 5824-5834, 2015.

Copyright (C) 2021 by the authors. This is an open access article distributed under the Creative Commons Attribution License which permits unrestricted use, distribution, and reproduction in any medium, provided the original work is properly cited (CC BY 4.0).

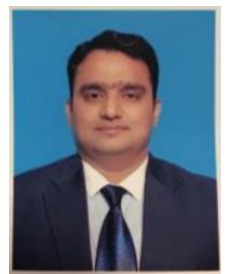

N. Gilany was born on April 2, 1976, in Pakistan. He got the MS (RS\&GIS), IGIS, NUST, Islamabad, Pakistan, 2011. The major field of study is alpine glaciers of northern areas of Pakistan.

$\mathrm{He}$ is vastly experienced in the field of glaciology. Works as visiting faculty of NUST. Currently he is enrolled as PhD scholar of IGIS, NUST. His area of research is glacial hazards of upper Indus River basins

\section{of Pakistan.}

Mr. Gilany has got presidential award on his professional work. His scientific studies are well acknowledged by the state.

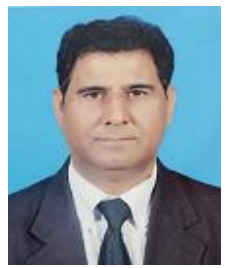

J. Iqbal is a Ph.D (GIS \& RS Application in Natural Resources Management, Mississippi State University, USA).

$\mathrm{He}$ is vastly experienced in the field of GIS and RS application in Natural Resource Management and works as HoD of IGIS, NUST.

Dr. Iqbal's scientific studies are well acknowledged by the state.

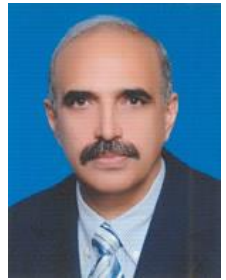

E. Hussain is a $\mathrm{PhD}$ (Geomatics Engineering, Purdue University, USA)

$\mathrm{He}$ is vastly experienced in the field of Geomatics Engineering and works as Associate Dean of IGIS, NUST.

Dr. Hussain's scientific studies are well acknowledged by the state. 